\title{
A „bértárgyalások” és a hozzájuk kapcsolódó munkajogi és munkaügyi kapcsolati kihívások a köztulajdonban álló vállalatok által müködtetett közszolgáltatások területén
}

\author{
Collective Wage Bargaining and the Related Challenges \\ of Labour Law and Labour Relations Regarding Public Services Operated \\ by Publicly Owned Companies
}

\begin{abstract}
ABSZTRAKT
Az állami és az önkormányzati közszolgáltatást nyújtó cégeknél több mint fél évig húzódott a 2021. évi bérfejlesztések rendezése, amely hároméves, úgynevezett „,jövedelempolitikai” megállapodásokban manifesztálódott. A folyamat azonban jelen írás szempontjából leginkább a munkaügyi kapcsolatok vetülete miatt vált érdekessé és jogtudományi szempontból is elemezhetövé. Az elemzés során - a terjedelem adta keretek lehetöségei között - vizsgálom a bérmegállapodások folyamatát (annak munkajogi tartalmával és következményeivel), a köztulajdonra vonatkozó eltérő kollektív munkajogi szabályok elvi alapjait, végül a szektor sztrájkjogi szabályozásának újonnan felmerülő gyakorlati problémáit.
\end{abstract}

Kulcsszavak: munkaügyi kapcsolatok, bértárgyalás, szakszervezetek, kollektív szerződés, közszolgáltatások

\begin{abstract}
In the case of state- and municipality-owned companies providing public services, the 2021 salary increase was settled with a six-monthly delay, which was manifested in three-year, so-called "income policy" agreements. However, for the purposes of this paper, the process became relevant mainly due to the aspect of labor relations and it also became suitable for a legal science analysis. During the course of this, within the available space limits, I discuss the process of salary negotiations (with its labor law content and consequences), the theoretical bases of the different collective labor law regulations regarding public assets, and finally, the newly emerging practical issues related to the strike rights regulation of this sector.
\end{abstract}

Keywords: labour relations, wage bargaining, trade unions, collective agreement, public services

* Dr. Szabó Imre Szilárd egyetemi adjunktus, Károli Gáspár Református Egyetem Állam- és Jogtudományi Kar, Munkajogi és Szociális Jogi Tanszék; munkajogász, Munkástanácsok Országos Szövetsége; e-mail: szabo. imre.szilard@kre.hu. 
megállapításaimat is - azt a vitatható zárógondolatot fogalmaztam meg, hogy bár a COVID-19 közvetlen gazdasági és munkaerőpiaci hatásai óvatos következtetéseket engednek: a „koronavírus-helyzet” egyik következménye, hogy bizonyos közszolgáltatások felértékelődtek, társadalmi megbecsülésük látványosan megnövekedett, ami kedvezőbb érdekérvényesítési helyzetbe hozhatja az e területen foglalkoztatott munkavállalókat, így - rajtuk keresztül - a munkavállalói érdekképviseleteket is. A humán közszolgáltatások egyes területein ez az állítás tételesen be is igazolódott (lásd például az orvosok keresetének korábban nem látott mértékü növekedését), ${ }^{2}$ ugyanakkor az úgynevezett „infrastrukturális”, a lakosságot alapvetően érintő közszolgáltatások területén (például vasúti és közúti közlekedési infrastruktúra müködtetése, postai, vízügyi szolgáltatások) - amelyek szintén a lakosság egészét szolgálják ki árukat vagy szolgáltatásokat nyújtva egyének, családok és közösségek számára ${ }^{3}$ - a megfogalmazott állítás igencsak ellentmondásos tartalmat nyert.

A felsorolt közszolgáltatások esetében - ellentétben a szolgáltatások más területeivel - a járvány idején még rövid időszakokra sem állt le a munka, sőt annak intenzitása sem csökkent, a járványügyi kockázat viszont kiemelkedően sújtotta a munkavállalókat. Mindazon túl, hogy az érintett területeken a munkavállalók megnövekedett megpróbáltatások közepette álltak helyt, érdemes arra is tekintettel lenni, hogy a közszolgáltatások fejlesztése (ami a tájékoztatások alapján az érintett területeken korábban nem látott mértékben zajlik) ${ }^{4}$ és a kapcsolódó munkahelyek megőrzése - a keresetek érzékelhető növelésével - pozitív hatást gyakorol az egész gazdaságra, segítve annak újraindítását. ${ }^{5}$ Mindezek ellenére az állami és az önkormányzati közszolgáltatást nyújtó cégeknél több mint fél évig húzódott a 2021. évi bérfejlesztések rendezése, amely hároméves, úgynevezett „jövedelempolitikai” megállapodásokban manifesztálódott.

A folyamat azonban jelen írás szempontjából leginkább a munkaügyi kapcsolatok vetülete miatt vált érdekessé és jogtudományi szempontból is elemezhetővé. Az elemzés során - az adott terjedelmi korlátok között - vizsgálom a bérmegállapodások folyamatát (annak munkajogi következményeivel), a köztulajdonra vonatkozó eltérő kollektív munkajogi szabályok elvi alapjait, végül a szektor sztrájkjogi szabályozásának újonnan felmerülő gyakorlati problémáit.

1 SzABó Imre Szilárd: Munkajogi elvi kérdések: a szociális párbeszéd és a kollektív szerződések mozgásteréröl. A járványhelyzet egyes munka- és szociális jogi dilemmái II. Glossa luridica, VII. különszám, 2020, 157-169.

2 Amelyet paradox - ugyanakkor a lobbierő miatt érthető - módon nem az egészségügyben müködő szakszervezetekkel tárgyalt meg a Kormányzat, hanem a szakmai köztestületként müködő Magyar Orvosi Kamarával.

${ }^{3}$ BILL, Jordan: Public services and the service economy. Journal of Social Policy, 2006/1, 143-162.

4 73,5 milliárdot költött tavaly a MÁV a Budapest-Belgrád vasútvonalra, www.hvg.hu https://hvg.hu/kkv/ 20210604_mav_2020_uzleti_ev_beszamolo (2021. 06.30.).

${ }^{5}$ SzABÓ Imre Szilárd-LAJTAI György: Van-e racionalitás 2021-ben érdemi bérfejlesztésre az állami cégeknél? https://szakszervezetek.hu/hirek/26341-szabo-imre-szilard-lajtai-gyorgy-van-e-racionalitas-2021-benerdemi-berfejlesztesre-az-allami-cegeknel (2021. 06. 01.). 


\section{A 2021. évi bérmegállapodások során felmerülö jogi és munkaügyi kapcsolatokat övező problémák a közszolgáltatási szektorban}

Az állami közszolgáltató vállalatok és a Fővárosi Önkormányzat által kötött bérmegállapodások ékes példái annak, hogy egyre inkább devalválódik a köztulajdonban müködő vállalkozások területén a bértárgyalások súlya és szerepe. Elsősorban (a korábbi évtizedekben tapasztaltaknál egyre inkább erőteljesebb és központosított módon) a tulajdonosi döntés kérdése, ${ }^{6}$ hogy a közpénz "gazdája” mire és mennyit fordít, ami önmagában determinálja a vállalati menedzsment és a munkavállalói érdekképviseletek mozgásterét. A „,bérpolitikai” dilemma tulajdonképpen abból fakad, hogy a bérezésnek egyszerre kellene tekintettel lennie a költségvetés szempontjára, de arra is, hogy vonzó és munkaerőt megtartó funkciót töltsön be, ${ }^{7}$ megfelelő alternatívát jelentve a „klasszikus” versenyszféra területén müködő munkáltatókkal szemben. A köztulajdon esetében a magántulajdonosok által irányított természetes monopólium szabályozása helyett maga az állam irányít, ${ }^{8}$ így a munkaügyi konfliktusok is hamar közpolitikai (és sokszor pártpolitikai) térbe kerülnek az érintett munkavállalók jelentős tömege okán.

\subsection{Az állami közszolgáltató társaságok helyzete}

A bértárgyalások az utóbbi években az ágazatközi, makroszintủ munkaügyi kapcsolatok területén kezdődnek, jellemzően a kötelező legkisebb munkabér (minimálbér) és a garantált bérminimum megállapításáról szóló kormányrendelet megjelenését követően. Ennek oka, hogy az éves növekmény egyfajta "orientációs pontot” is jelent a szereplők számára. Ezt azért is szükséges kiemelni, mert érezhetően hiányzik a „bérajánlás” intézménye - amely ugyan a versenyszféra és a Kormány Állandó Konzultációs Fóruma keretében kötött megállapodásokban is időnként ${ }^{9}$ szerepel -, de korábban eröteljesebben jelen volt az Országos Érdekegyeztető Tanácsban (OÉT) ${ }^{10}$ zajló (minimálbér)megállapodások esetében, ahol a szociális partnerek és a kormány minden évben megállapodtak abban, hogy a bruttó keresetek milyen mértékủ növelését (jellemzően alsó-felső határos keresetnövelési sávokat) ajánlják a vállalkozási szférának és a kollektív bértárgyalásokat folytató szociális partnereknek. Ennek ellenőrzését a kollektív szerződések nyilvántartási rendszerébe beérkezett adatok szerint kísérelték meg, amelynek tapasztalata alapján a vállalati megállapodások túlnyomó többsége az OÉT ajánlás keretei között jött létre.

\footnotetext{
${ }^{6}$ A tulajdonos nélkül nem megy, https://www.vsz.hu/hirek/mavcsoport/korabbi-hireink/a-tulajdonos-nelkul-nemmegy/ (2021. 06. 29.).

${ }^{7}$ LőRINCZ György: Mi lesz veled, Kjt.? Munkajog, 2021/2, 17.

${ }^{8}$ MANKIW, N. Gregory: A közgazdaságtan alapjai. Osiris, Budapest, 2011, 336.

${ }^{9}$ Lásd a 2018. évi megállapodást: https://munkastanacsok.hu/tajekoztato-a-vkf-ben-kotott-2019-2020-evekreszolo-minimalber-es-garantalt-berminimum-emeleserol/ (2021. 07. 27.).

10 2011-ig müködő tripartit összetételü érdekegyeztető fórum, amely a munka világával összefüggő kérdésekröl, a jövedelemelosztásról, illetve ezzel összefüggésben a gazdaságpolitikai keretekröl folytatott tárgyalásokat, illetve kötött országos megállapodásokat. Helyébe a 2011. évi XCIII. törvény alapján a Nemzeti Gazdasági és Társadalmi Tanács lépett.
} 
Napjaink gyakorlatát az érdekképviseletek által évek óta javasolt Közszolgáltató Vállalkozások Konzultációs Fóruma (továbbiakban: KVKF) jelenti. A fórumot egy együttmüködési megállapodás hozta létre, melyet a KVKF 16 tagjának képviselői írtak alá. A KVKF az ügyrendje ${ }^{11}$ értelmében a köztulajdonban müködő, közszolgáltatásokat közvetlenül érintő gazdasági tárgyú kormányzati döntések előkészítésében közremüködő háromoldalú konzultatív, véleményező és javaslattevő fórum, mely szervezeti keretet biztosít a köztulajdonban müködő közszolgáltatást végző vállalatok országos és ágazati munkaadói, illetve munkavállalói szereplőinek, valamint a Kormánynak azzal a céllal, hogy rendszeres egyeztetéseket folytassanak a munkabéke megőrzése érdekében. A KVKF ügyrendje szerint a munkavállalói oldal tagjai a köztulajdonban működő közszolgáltatásokat végző vállalkozások (al)ágazati szinten reprezentatív szakszervezetei, továbbá a versenyszféra és a Kormány Állandó Konzultációs Fórumának országos munkavállalói érdekképviseletei. A „reprezentativitás" megállapítását az ügyrend a felekre bízza. Munkáltatói oldalról a nagyobb közüzemeket tömörítő Stratégiai és Közszolgáltató Társaságok Országos Szövetsége alanya a fórumnak, amelynek munkájában a nemzeti vagyon kezeléséért felelős tárca nélküli miniszter, a Pénzügyminisztérium és az Innovációs és Technológiai Minisztérium képviselői vesznek részt. A fórum keretében már létrejött egy megállapodás 2017-ben, amely alapján a nagyobbrészt közszolgáltatásokat ellátó állami vállalatok munkavállalói három év alatt átlagosan 30 százalékos bérfejlesztésben részesültek, ${ }^{12}$ míg 2020-ban, a pandémia évében jellemzően 10 százalékos bérfejlesztés történt.

Az idén júniusban lezárt tárgyalások eredményeként 2021. július 1-től évente átlagosan 5 százalékkal, 2023-ig összesen 15 százalékkal nő a megállapodásban érintett társaságok munkavállalóinak bére. A hároméves bérfejlesztés évenkénti mértéke társaságonként eltérő lehet. Így például, míg a MÁV-Volán Csoport 2022-ben és 2023-ban 10-5 százalékkal emeli a béreket (kiegészítve azt egyösszegü, egyszeri juttatásokkal), addig a Magyar Postánál 2021-ben 4 százalékkal, 2022-ben 9 százalékkal, 2023-ban pedig 2 százalékkal nő a postások alapbére. ${ }^{13} \mathrm{~A}$ Nemzeti Vízmúveknél dolgozók alapbére 2021-ben 4, 2022-ben 7, 2023-ban 4 százalékkal emelkedik. ${ }^{14} \mathrm{~A}$ tárgyalások sorát a villamosenergia-ipar zárta, ahol az MVM Társaságcsoporti Szakszervezeti Szövetség és a Magyar Villamos Művek menedzsmentje szintén három évre szóló keresetfejlesztési megállapodást kötött. ${ }^{15} \mathrm{~A}$ szakszerveze-

${ }^{11}$ Együttmüködési megállapodás a Közszolgáltató Vállalkozások Konzultációs Fórumáról, https://munkastanacsok. hu/wp-content/uploads/2018/02/meg\%C3\%A1llapod\%C3\%A1s-\%C3\%A9s-\%C3\%BCgyrend.pdf (2021. 07. 01.).

12 Sikeresnek ítélték az állami vállalatok hároméves bérfejlesztését, https://magyarnemzet.hu/gazdasag/sikeresnekiteltek-az-allami-vallalatok-harom-eves-berfejleszteset-6856889/ (2021. 06. 30.).

${ }^{13}$ A postások is aláírták a megállapodást, https://liganet.hu/10945-a-postasok-is-alairtak-a-megallapodast.html (2021. 07. 01.).

${ }^{14}$ Amely egyelőre nem vonatkozik részben önkormányzati, részben állami tulajdonban lévő társaságra, Id. az Alföldvíz Zrt. munkavállalóinak tiltakozását. Bod Tamás: Ismét Orbán irodájához vonulna az Alföldvíz Zrt. szakszervezete, https://magyarnarancs.hu/kismagyarorszag/ismet-orban-irodajahoz-vonulna-az-alfoldvizzrt-szakszervezete-239750 (2021. 07. 01.).

${ }^{15}$ Hároméves bérmegállapodás az MVM Zrt.-nél, https://www.liganet.hu/10952-haromeves-bermegallapodasaz-mvm-zrt-nel.html (2021. 07. 01.). 
tek kiemelték, ${ }^{16}$ hogy az egyes megállapodások a vállalati szinten lefolytatott tárgyalások eredményeit tükrözik, így jogi tartalmukat tekintve a kollektív szerződést kötő felek által történő aláírást követően realizálódhatnak. A felek fontos szempontnak tartják, hogy a Közszolgáltató Vállalkozások Konzultációs Fóruma - noha különböző (például postai, víziközmü-, közúti és vasúti személyszállítási, villamosenergia-ipari stb.) közszolgáltatásokat nyújtó munkáltatókat képvisel - az állam tulajdonosi szerepe okán a továbbiakban is alkosson érdemi keretet a speciális vállalati szektorban zajló kollektív alkunak. A megállapodásokat több érdekképviselet is éles kritikával illette, és távolmaradt azok aláírásától. ${ }^{17}$

Az egyértelmű jogi meghatározás kapcsán további kérdéseket vetnek fel a nyilvánosságra került dokumentumok. A MÁV-csoport jövedelempolitikai megállapodást írt alá a szakszervezetek egy részével. ${ }^{18} \mathrm{Az}$ abban foglaltak végrehajtását a konszolidációs körébe bevont gazdasági társaságok esetében a MÁV Zrt. tulajdonosként biztosítja. Nem vitatható, hogy a foglalkoztatás általános feltételeinek kialakítása és biztosítása a tulajdonosi jogokat gyakorló döntési jogkörébe tartozik; ugyanakkor a kollektív munkajog területén az érdekegyeztetés folyamatában (jogszabályi szinten) nincsenek nevesítve, megjelölve a tulajdonosi jogot gyakorló személy és a szakszervezetek ehhez kapcsolódó, meghatározott jogosítványai sem. A megállapodás személyi hatálya ennek ellenére kiterjed a MÁV-csoporthoz tartozó egyes munkáltatókra is. ${ }^{19}$

Okkal merül fel a kérdés, hogy mi a megállapodás jogi tartalma. Vajon egy esetleges - megállapodással szemben megvalósuló - munkabeszüntetés megszervezése az úgynevezett sztrájkjogi „,békekötelembe”20 ütközne? Jelen kézirat lezárásáig (2021 augusztusa) nincsen arra vonatkozó információ, hogy a ,jövedelempolitikai megállapodást" vállalati bérmegállapodások erősítették volna meg, ugyanakkor álláspontom szerint csak így minősülhetnek ezek a bérmegállapodások egyben vállalati kollektív szerződéseknek is. Persze csak akkor, ha az abban részes felek mind-

${ }^{16}$ Hároméves bérmegállapodás a legnagyobb közszolgáltató vállalatoknál, https://kormany.hu/hirek/haromevesbermegallapodas-a-legnagyobb-kozszolgaltato-vallalatoknal (2021. 07. 01.).

${ }^{17}$ Magyar Posta: Állami bérmegállapodások: a postánál két szakszervezet nem írta alá, https://szakszervezetek.hu/dokumentumok/mibol-elunk/27037-allami-bermegallapodasok-a-postanal-ket-szakszervezet-nem-irtala (2021. 06. 29.).

MÁV-VOLÁN csoport: A mozdonyvezetők szakszervezete nem kér a MÁV bérmegállapodásból, https://hvg. hu/kkv/20210625_mozdonyvezetok_szakszervezete_mav_bermegallapodas (2021. 06. 29.), Dobi István: A KDSZ egységesen visszautasít minden olyan megállapodást, amely nem tartalmazza az alapbérek 2021-re vonatkozó érzékelhető emelését, https://kdszsz.hu/a-kozlekedesi-dolgozok-szakszervezeteinekszovetsege-kdszsz-egysegesen-visszautasit-minden-olyan-megallapodast-amely-nem-tartalmazza-azalapberek-2021-re-vonatkozo-erzekelheto-emeleset/ (2021. 06. 29.).

${ }^{18}$ Megállapodás a 2021-2023. évi jövedelempolitikai intézkedésekröl, 22458/2021/MAV. https://www.vdszsz. hu/images/a8473/Ber2021_2023_megallapodas.pdf (2021. 06. 29.).

${ }^{19}$ MÁV Zrt., MÁV-START Zrt., MÁV Szolgáltató Központ Zrt., MÁV-HÉV Zrt., VOLÁNBUSZ Zrt., MÁV FKG Kft., MÁV KFV Kft., ZÁHONY PORT Zrt., MÁV VAGON Kft., MÁV Rail Tours Kft.

${ }^{20}$ A békekötelem lényege a sztrájk, illetve egyéb kollektív munkavállalói tiltakozó akciók tilalma a kollektív szerződés hatálya alatt. Az e mögötti legföbb gondolat, hogy a kollektív szerződés alanyai (különösen a szakszervezetek) tartózkodjanak minden olyan cselekménytöl, amely a megállapodásban foglaltak sikeres teljesítését akadályozhatja, biztosítva ezzel a munkabéke fennmaradását. Ezt a szabályt tételesen a Sztrájktv. 3 . § (2) bekezdése tartalmazza. 
egyike egyetért annak tartalmával, a kollektív szerződés módosítására vonatkozó szabályoknak megfelelően, külön betartva az Mt. 276. § (8) bekezdésében foglalt követelményt is, amely sajátos kihívást jelent a megállapodás hatálya alá tartozó munkáltatók esetében.

A hivatkozott jogszabályhely két súlyos problémát is okoz, ami a 2021. évi megállapodások során is elötérbe került.. ${ }^{21}$ Egyrészt ellentmondásokkal terhelt (egyfajta „konstrukciós hiba”) az a jogi helyzet, ha a szakszervezet vagy a szakszervezeti szövetség a kollektív szerződés megkötését követően felel meg a kollektív szerzödéskötési képesség feltételeinek. A szakszervezetek szervezettsége (és így annak aránya) - természetszerüleg - folyamatosan változhat. Az Mt. hatálybalépése óta eltelt években számos olyan eset fordult elö, hogy egy időközben megerősödött (a megkötő fél oldaláról nézve sokszor ezzel egyidejüleg jelentéktelenné váló) szakszervezet nem tudott alanyává válni a kollektív szerződésnek, ugyanis a kollektív szerződés módosítására a megkötésére vonatkozó szabályok irányadók (ideértve az alakiságra vonatkozó kellékeket is). ${ }^{22} \mathrm{~A}$ módosításra pedig csak a kollektív szerződést kötő felek jogosultak. Így az a szakszervezet, amely a kollektív szerződés megkötését követően felel meg az úgynevezett „10\%-os” szervezettségi feltételnek, jogosult a kollektív szerződést kötő felekhez intézett jognyilatkozattal a kollektív szerződés módosítását kezdeményezni, és a módosítással kapcsolatos tárgyaláson - tanácskozási joggal - részt venni. Felmondani nem jogosult azt (tekintve, hogy annak nem alanya), ráadásul a tanácskozási jog is egy kontúrtalan jogintézmény e tekintetben (a törvény ebben az esetben csupán az újratárgyalásra ad lehetőséget). A rendelkezés jelenleg hatályos tartalma („csak az módosítsa, aki kötötte”) látványosan nem illeszkedik bele az Mt.-nek a kollektív szerződéskötési képességgel kapcsolatos szabályrendszerébe, ugyanis a kollektív szerződéskötési képességet nem lehet sem az általános jogképességgel, sem a cselekvőképességgel azonosítani. A kollektív szerződéskötési képesség ugyanis csak meghatározott jogügylet (a kollektív szerződés) létrehozására irányuló sajátos alanyi képesség, ugyancsak sajátos (alanyi érvényességi) kellékekkel.

Összességében a hatályos szabályozás lényegében azt eredményezi, hogy hiába válik a kollektív szerződés megkötését követően egy szakszervezet jelentőssé, ameddig fennáll a kollektív szerződés, lényegében kiszorul annak módosításából, így nem tud érdemi befolyást gyakorolni a munkafeltételek alakítására. Ráadásul munkajogász szakmai körökben is vitatott az az alapvetően polgári jogi (kötelmi jogi) kérdés is, hogy a kollektív szerződéses felek egyező akaratából lehet-e új (később kollektív szerződési képességet szerző) alanya egy kollektív szerződésnek. Az egyik álláspont szerint, amennyiben szerződéskötő félként csatlakozik az eredeti

${ }^{21}$ A MÁV-VOLÁN csoportnál a megállapodástól távol maradó két szakszervezet teljesíti a MÁV-START Zrt.-nél (Mozdonyvezetők Szakszervezete), illetve a VOLÁNBUSZ Zrt.-nél (Közlekedési Dolgozók Szakszervezeteinek Szövetsége) Mt. 276. § (2) bekezdésében foglalt feltételeket, viszont nem alanyai a kollektív szerződéseknek.

${ }^{22}$ Az 1992-es Mt. 39. § (5) bekezdésében foglalt szabályozáshoz, amely szerint az újabb üzemi tanácsi választásokon kollektív szerződéskötési képességet szerzett szakszervezet felmondhatta a kollektív szerződést. 
felek egyetértésével, az az eset új kollektív szerződésként értelmezhető, ${ }^{23}$ míg az ezzel ellentétes értelmezés a kötelmi jog általános tanaiból indul ki. A probléma noha elméletinek (és technikai kérdésnek) hat, a köztulajdonban álló munkáltatónál azért válik külön érdekessé, mivel a kollektív szerződés a végkielégítés Mt.-ben megállapított szabályaitól, ideértve annak mértékét is, nem térhet el, ${ }^{24}$ amely szabályt azonban csak az Mt. hatálybalépését követően kötött kollektív szerződésre kell alkalmazni. ${ }^{25}$ Így amennyiben azt az álláspontot fogadjuk el, hogy az alanyok bővítése új kollektív szerződést eredményez, akkor esetleges korábbi vívmányoktól (plusz juttatásoktól) eshetnek el a munkavállalók (a felmondási idő, illetve a végkielégítés munkavállalói szempontból kedvező korábbi eltérései miatt), ami az „új” kollektív szerződés esetében már az Mt. hivatkozott szakaszába ütközne.

A fenti probléma nemcsak jogi természetü, hanem a munkaügyi kapcsolatok oldaláról egy - elöre nem látható - nehézséget is okoz a munkáltató és a kollektív szerződésben részes szakszervezet(ek) számára. A kollektív szerződésen kívül rekedő szervezet kvázi „tét nélkül” tárgyal (nincs megállapodási kényszere), így érdemben (jogi értelemben) semmi nem köti, ami szakszervezeti szempontból amellett, hogy „kényelmes” pozíció, a populista kommunikáció lehetőségét is jelenti. A Kormány korábban már két ízben kezdeményezte, majd visszavonta a kapcsolódó jogszabálymódosítást, amely helyreállítaná a kollektív szerződések „közjogias” természetét, miszerint nem szimplán egyszerű szerződéses (kötelmi) alanyiságról van szó, hanem egyfajta normaalkotási képességröl, felhatalmazásról. ${ }^{26}$ A 2021-es év tapasztalata után „le kellene porolni” és ismét előterjeszteni a fentiekben is jelzett gyakorlati problémák feloldására. ${ }^{27}$

\subsection{A Fővárosi Önkormányzat által kötött „bérmegállapodás”}

A köztulajdon másik aspektusát adja az önkormányzati tulajdonban álló közmüvállalatok helyzete, amelynek szintén plasztikus esete a 2021 júniusában kötött egyezség. A fővárosi „bérszövetséget” alkotó szakszervezetek képviselői, valamint a Fővárosi Önkormányzat nevében eljáró főpolgármester írt alá egy 2021-2024 közötti időszakra vonatkozó, fővárosi bérpolitikai megállapodást. ${ }^{28} \mathrm{~A}$ megállapodás értelmében 2022 és 2024 között az egyes munkáltatók és a náluk müködő szakszervezetek a minimálbérről szóló kormányrendelet kihirdetését követő 30 napon belül, de legkésőbb a tárgyév február 15-éig megállapodnak az adott évre vonatkozó bér-

${ }^{23}$ Berke Gyula-Bankó Zoltán-Szabó Imre Szilárd: Prevenció. A tanácsadás lehetősége a Munkaügyi Tanácsadó és Vitarendező Szolgálat keretében. HVG-ORAC, Budapest, 2017, 25.

${ }^{24}$ Mt. 205. § (1) bekezdés b) pont.

25 2012. évi LXXXVI. törvény a munka törvénykönyvéröl szóló 2012. évi I. törvény hatálybalépésével összefüggő átmeneti rendelkezésekröl és törvénymódosításokról (Mth.), 11. § (1).

${ }^{26}$ Azzal, hogy az a szakszervezet (szakszervezeti szövetség), amely a kollektív szerződés megkötését követően felel meg a jogosultsági feltételnek, a kollektív szerződéshez félként csatlakozhat, miután az erre vonatkozó jognyilatkozatát tizenöt napon belül a szerződéskötő felekkel írásban közli.

27 T/8013. számú törvényjavaslat. Ld. bővebben SzABó Imre Szilárd: A szakszervezetek jogállása a magyar munkajogban. Doktori Értekezés, Pécs, 2021, 153.

${ }^{28}$ Közölte a Fővárosi Önkormányzat és a Magyar Szakszervezeti Szövetség. https://infostart.hu/gazdasag/ 2021/06/03/megszuletett-a-bermegallapodas-budapesten (2021. 06. 28.). 
fejlesztés végrehajtásáról. Ennek mértéke megegyezik a minimálbér- és garantált bérminimum-emelés százalékos mértékeinek számtani átlagával. $A$ jogi kérdés ebben az esetben elsősorban az, hogy a munkáltatói szintű kollektív szerződéses megállapodások szintjén hogyan „realizálható” az ilyen kollektív alkufolyamatba illesztett politikai vállalás. Tartalmilag ugyanaz a probléma merül fel, mint az állami közszolgáltató vállalkozások esetében, kiegészítve azzal, hogy a „bérszövetség” nevében aláíró érdekképviseletek kollektív szerződéses alanyi köre sem egyértelmü; azaz, hogy a munkáltatói szinten megkötendő egyes megállapodásokban (például FKF Nonprofit Zrt., FÖTÁV, Budapesti Közlekedési Központ Zrt.) részes szakszervezetek teljes egyezőséget mutatnak-e az ad hoc koalícióként létrejövő „bérszövetség” tagjaival. Ezzel a szakszervezetek körében is érdekviták merülhetnek fel, hogy ki, milyen szinten és jogi kötőerővel szignálja a végső vállalati megállapodásokat.

\section{A munkaügyi kapcsolatok szabályozásának további kérdései; kollektív tárgyalási lehetöség a tulajdonossal, és a köztulajdon eltérő szabályozásának kérdései}

A köztulajdonban álló cégeknél a munkaügyi kapcsolatokra vonatkozó szabályok - kizárólag (jog)politikai alapon - kógensek (azaz a szerződő felek még egyező akarattal sem térhetnek el), aminek az alapját (részben) az képezte, hogy a köztulajdonban álló munkáltatók munkajogi gyakorlatában visszaélésszerū megállapodások is kialakultak mind az egyéni munkaviszonyokban, mind pedig a kollektív munkaügyi kapcsolatokban. ${ }^{29} \mathrm{Az}$ Mt. 204. § értelmében köztulajdonban álló munkáltató a közalapítvány, valamint az a gazdasági társaság, amelyben az állam, helyi önkormányzat, nemzetiségi önkormányzat, önkormányzati társulás, térségi fejlesztési tanács, költségvetési szerv vagy közalapítvány külön-külön vagy együttesen számítva többségi befolyással rendelkezik. Többségi befolyás az a kapcsolat, amelynek alapján a befolyással rendelkező jogi személyben a szavazatok több mint ötven százalékával - közvetlenül vagy a jogi személyben szavazati joggal rendelkező más jogi személy (köztes vállalkozás) szavazati jogán keresztül - rendelkezik. Az Mt. 90. fejezete külön szabályokat rendel alkalmazni a köztulajdonban álló munkáltatóknál fennálló munkaviszonyokra. Megjegyzendő, hogy a köztulajdonban álló munkáltatókra vonatkozó különös szabályok általános jellemzője az, hogy e tekintetben viszonylag széles körben érvényesül az egyéni és kollektív viszonyokba való állami korlátozás/ beavatkozás, aminek az indokolásaként a köztulajdon (közvagyon) védelme szerepel, amit a jogalkotó kiemelt jogpolitikai célként fogalmazott meg. ${ }^{30}$

A köztulajdonban álló munkáltatókra vonatkozó törvényi korlátozások körében különös helyet foglal el az Mt. 206. §-a, amely napjainkban heves viták kereszttüzében áll. Lörincz György korábban idézett írásában a köztulajdonban álló munkáltatókra de lege ferenda javaslatot tesz azzal, hogy a tulajdonosi jogkörök ,...konzekvenciáját a munkajognak a kollektív jogok gyakorlásának szabályozásánál kell levon-

\footnotetext{
${ }^{29}$ Lásd Mt. Általános Indokolás 22. pont, illetve Részletes Indokolás a 204-207. §-hoz.

${ }^{30}$ Lásd bővebben BERKE Gyula-PETROvics Zoltán: Kollektív munkaügyi viták és az alternatív vitarendezés lehetöségei a közüzemek területén. HVG-ORAC, Budapest, 29.
} 
nia, így az érdekegyeztetés folyamatában nevesítve megjelölve a tulajdonosi jogot gyakorlót, mint akivel/amellyel szemben a munkavállalói képviselők meghatározott jogosítványokkal rendelkeznek". ${ }^{31}$ A hivatkozott megállapítással maradéktalanul egyetértek, a fenti példák ellentmondásai is indokolják a jogalkotó „beavatkozását”. A munkaügyi kapcsolatok területén megfogalmazódik az az állítás is, hogy az azokra vonatkozó korlátozásokat „el kellene törölni”, tekintve, hogy „a túlnyomórészben jóhiszemü joggyakorlást is korlátozzák" ${ }^{32}$ Ezen a szemléletmódján az államnak érdemben szükséges változtatnia, nagyobb mozgásteret biztosítva a vállalati menedzsmentek számára.

Kétségtelen mindenesetre az, hogy az Mt. 205-206. §-ai a kollektív megállapodásos szabadsággal kapcsolatosan olyan megoldást hoztak létre, amely alkotmányossági szempontból is megfontolást érdemel. Az Alaptörvény XVII. cikkéből következhet-e az úgynevezett kollektív szerződéses autonómiának olyan korlátozása, amely a köztulajdonban álló munkáltatók esetében érvényesül? Másként: az Alaptörvény említett rendelkezése lehetővé teszi-e azt, hogy a jogalkotó a kollektív szerződéses autonómiát többféle tartalommal határozza meg (mintegy megkettőzze), s hogy különösen a munkáltató tulajdonosi hátterére tekintettel eltérő szabályokat alkosson? A hazai munkajogi irodalomban egyes álláspontok szerint az Mt. tulajdonképpen kétféle szakszervezetet különböztet meg, illetve az egyik szakszervezet (a köztulajdonú cégeknél működő) koalíciós szabadságát (alapjogát) eltérően korlátozza, mint a másikét, és ezzel tulajdonképpen e szakszervezetek számára kizárja azt a lehetőséget, hogy bizonyos kérdésekben érdemi kollektív tárgyalásokat folytassanak, illetve megállapodást kössenek. ${ }^{33}$ Berki Erzsébet arra hívja fel a figyelmet, hogy a köztulajdonban álló munkáltatók szakszervezeteit a törvény tulajdonképpen három oldalról is sújtja: 1 . Az „új” Mt. által hozott szakszervezeti pozíciók általános lerontása ezen a területen is érvényesül; 2 . Korlátozott annak a lehetösége, hogy a szakszervezetek a kollektív szerződés kötelmi rendelkezései útján jobb helyzetbe kerüljenek, mint a törvényi minimum; 3 . Az eltérő normatív szabályok korlátozzák a munkavállalók érdekeinek érvényesítését. ${ }^{34,35}$

${ }^{31}$ LőRINCZ: i. m., 17.

32 LŐRINCZ: i. m., 17.

${ }^{33}$ Lásd bővebben FODOR T. Gábor-SzABÓ Imre Szilárd: Néhány gondolat a köztulajdonban álló munkáltatókra vonatkozó munkajogi szabályozás munkaügyi kapcsolatokra gyakorolt hatásairól. In: Petrovics Zoltán (szerk.): XIV. Magyar Munkajogi konferencia. Wolters Kluwer, Budapest, 2017; BerkE Gyula-PETROVICS Zoltán: Kollektív munkaügyi viták és az alternatív vitarendezés lehetőségei a közüzemek területén. HVGORAC, Budpest, 2018.; FERENCZ Jácint-Fodor T. Gábor-Kun Attila-TRENYISÁN Máté: Az Mt. szabályrendszeréből adódó új érdekképviseleti szempontok érvényesitési lehetőségei (Kollektív alku a köztulajdonban álló munkáltatóknál). Egyesült Villamosenergia-ipari Dolgozók Szakszervezeti Szövetsége, Budapest, 2014. http://www.vd.hu/tamoptanulmanyok/2014-szeptember-30-10794.html. (2019. 12. 13.).

34 „205. § (1) Kollektív szerződés vagy a felek megállapodása a) a felmondási idő 69. § (1)-(2) bekezdésében és (4)-(5) bekezdésében, valamint b) a végkielégítés 77. §-ban meghatározott szabályaitól nem térhet el. (2) A köztulajdonban álló munkáltatóval fennálló munkaviszonyban a) a 69. § (3) bekezdése nem alkalmazható, b) a 86. § (3) bekezdésétöl nem lehet eltérni. (3) A köztulajdonban álló munkáltatóval fennálló munkaviszonyban az általános teljes napi munkaidőnél rövidebb teljes napi munkaidő - az egészségi ártalom vagy veszély kizárása érdekében történő megállapítást kivéve - nem írható elő."

${ }^{35}$ BERKI Erzsébet: Kollektív szerződés köztulajdonban álló munkáltatónál. In: Kiss György (szerk.): Szakszervezetek és kollektív szerződések az új munka törvénykönyvében. Akadémiai Kiadó, Budapest, 2015, 71. 
A kérdés így alapvetően az, hogy lehet-e a köztulajdonban álló munkáltatóknál alkotmányosan eltérően szabályozni a kollektív autonómia tartalmát és határait, mint általában a munkajogban, így a munkáltató tulajdoni forma alapján való jogi megkülönböztetése (mint alapjog-korlátozó rendelkezés) megfelel-e az alapjog-korlátozás tesztjének (szükséges, alkalmas és arányos). Az alapvető jogok biztosa az egyik vasutas szakszervezet beadványára adott válaszként kifejtette, hogy a köztulajdonban álló munkáltatók vegyes jellegüek, mivel formálisan a versenyszféra (magánszféra) munkáltató közé tartoznak, míg a rájuk irányadó szabályok tartalmukat tekintve inkább kógens és közjogi jellegűek. ${ }^{36}$ Minderre figyelemmel a köztulajdonnal való hatékony gazdálkodás követelménye teszi azt szükségessé, hogy a szerződési szabadság és a kollektív alku intézménye korlátozásra kerüljön a köztulajdonban álló munkáltatók esetében. Álláspontom szerint (osztva a panaszos véleményét) a köztulajdon védelme kifejezetten a szakszervezetekkel szemben - a kollektív alku intézményének korlátozása által - sem nem szükséges, sem nem arányos, hiszen maga a kollektív megállapodások létrejötte a köztulajdonban sem képzelhető el a másik fél, jelen esetben a (köz)tulajdonos, illetve a menedzsment aktív közremúködése nélkül. Tulajdonképpen a végső kérdés arra szűkül le, hogy az állam megbízik-e a saját irányítása alatt álló munkáltatók vezetésében. Mindazonáltal a „különös szabályozás" a köztulajdonban álló munkáltatóknál a rendszerváltozást követően sem előzmények nélküli. ${ }^{37}$ A korábbi Mt. egy 1995-ben bevezetett rendelkezése ${ }^{38}$ a határozott idejü munkaviszonyok megszüntetésekor megfizetendő munkadíj összegét korlátozta. ${ }^{39}$

\section{3. Érdemi nyomásgyakorló eszköz - a sztrájkjog helyreállítása}

Érdemi munkavállalói nyomásgyakorló eszközök nélkül az Mt. korrigált munkaügyi kapcsolatokra vonatkozó joganyaga sem minősül önmagában elégségesnek. Álláspontom szerint a közszolgáltató szektorra vonatkozó sztrájkjogi szabályokat is érdemben szükséges módosítani, amelyek jelenleg az alábbi gyakorlati problémák révén teszik lehetetlenné e jog gyakorlását, ismeretlen jelenséggé téve a munkabeszüntetéseket.

Lassan tizenegy év telt el a sztrájktörvény - átfogónak is nevezhető - módosítása óta. Ez az évtized elegendő gyakorlati tapasztalatot is hozhatott volna a kérdés megválaszolására, ugyanakkor a szabályozást övező vitákban továbbra is sokszor a bizonytalanság tűnik az egyetlen bizonyosságnak. A rendszerváltáskor

\footnotetext{
36 Ügyszám: AJB-612/2017.

${ }^{37}$ Erröl részletesen BERKE Gyula: A köztulajdonban álló munkáltatók különös munkajogi szabályozása. In: Kehl Dániel-Rappai Gábor (szerk.): Primus inter pares: tanulmánykötet Hoóz István 90. születésnapja tiszteletére. Pécsi Tudományegyetem Közgazdaságtudományi Kar, Pécs, 2018, 13-26.

38 1992. évi XXII. törvény 88. § (2).

39 Berke Gyula a szabályozásról megállapította, hogy a „korlátozás ellentmondásosra sikerült, hiszen noha az Mt. legfeljebb egy évi átlagkereset összegében korlátozta a kifizethető munkadij összegét, azonban a szabálytól a munkavállaló javára érvényesen el lehetett térni (a munkaviszonyban álló felek megállapodásában vagy kollektív szerződésben is)". BERKE (2018): i. m., 10.
} 
elfogadott 1989. évi VII. törvény a sztrájkról (a továbbiakban: Sztrájktörvény vagy Sztv.) legnagyobb vitákat kiváltó rendelkezése a „még elégséges szolgáltatás” biztosításához kapcsolódott. ${ }^{40} \mathrm{~A}$ törvény megszületésekor úgy rendelkezett, hogy a lakosságot alapvetően érintő tevékenységet végző munkáltatónál a sztrájkjog csak úgy gyakorolható, hogy az a még elégséges szolgáltatás teljesítését ne gátolja. Ennek mértékét és feltételeinek meghatározását a jogalkotó a sztrájkban érintett felek megállapodására bízta. A törvény indokolása szerint a javaslat korlátozni kívánta a sztrájkjog gyakorlását azoknál a munkáltatóknál, amelyeknek müködése a társadalom alapvető napi létezésének szempontjából elengedhetetlen. Ilyenként említette a közforgalmú közlekedést, energiaszolgáltatást, távközlést azzal, hogy a felsorolás példálózó jellegű, adott esetben egyéb tevékenységet (például óvodáskorúak, tanulók felügyeletét) is e körbe lehet sorolni. Ennek alkalmazása azonban további bizonytalanságokat hordozott. A megállapodás hiánya a munkavállalók sztrájkba lépését nem akadályozta meg, és a Legfelsőbb Bíróság egyik 1991-es eseti döntése alapján nem szolgálhatott a sztrájk jogellenességének megállapítása alapjául sem (BH 1991. 255.). Ezt erősítette meg jóval később az EBH 2008. 1814. számú határozat is, amely szerint a kollektív szerződés a sztrájktörvénnyel ellentétesen nem írhatja elö, hogy sztrájk jogszerủen csak a még elégséges szolgáltatás mértékében való megállapodás esetén tartható.

A Sztrájktörvényt módosító törvény az elégséges szolgáltatás meghatározásának új metódusát alakította ki 2010. december 31-ei hatállyal, amely ellen a szakszervezetek azóta is élesen tiltakoznak, különösen a közszolgáltatások területén. A módosítás alapján a törvény új bekezdésekkel egészült ki, amelyek értelmében az elégséges szolgáltatást a lakosságot alapvetően érintő tevékenységet végző munkáltatók esetében törvény állapíthatja meg. ${ }^{41}$

A szerencsésnek nem nevezhető jogszabályi konstrukció így abból indul ki (arra utal), hogy megállapodás csak akkor kell, ha nincs törvény. Ugyanakkor az ágazati törvények bizonyos területeken egyáltalán nem képesek a sztrájk folytatásának részletes szabályait megállapítani (gondoljunk arra, hogy ez milyen szabályozást jelentene a vízügyi szolgáltatások vagy éppen a villamosenergia-ellátás területén). Törvényi szabályozás hiányában a sztrájkot megelőző egyeztetés során kell a még elégséges szolgáltatás mértékéröl és feltételeiről megállapodni; ebben az esetben a sztrájk akkor tartható meg, ha a felek a megállapodást megkötötték, vagy ennek meghiúsulása esetén bármelyikük kérelmére a bíróság jogerős határozata megállapította a még elégséges szolgáltatás mértékét és feltételeit. Ebből következik az a sorrend, amely alapján elsődlegesen törvény szabályozza a feltételeket, ennek hiányában a felek megállapodása, míg végső esetben - amennyiben sem törvény, sem a felek megállapodása nem szabályozza a kérdést - kerülhet sor a bíróság döntésére. A módosítás így teljesen szakított a korábbi konstrukcióval: ha sem törvény, sem

${ }^{40}$ Lásd bővebben KAJTÁR Edit-Kun Attila: Right to Strike in a Changing Regulatory Environment. Pázmány Law Working Papers, 2013/03, 8., 11.; SzABÓ Imre Szilárd: A sztrájk jogintézményének elmúlt 20 évéről. In: Miskolczi Bodnár Péter-Kun Attila-Boóc Ádám (szerk.): Gazdaság és jog: húsz év jogalkotási fejleményei a civilisztika területén. KRE ÁJK, Budapest, 2019, 257-274.

${ }^{41}$ Sztv. 4. § (3)-(4) bekezdése. 
a felek megállapodása, sem pedig jogerős bírói határozat a még elégséges szolgáltatás mértékéről és feltételeiről nem rendelkezik, jogszerü sztrájk nem tartható. ${ }^{42}$ A döntések elhúzódását igyekszik meggátolni, hogy a bíróságoknak öt munkanapon belül, nem peres eljárásban kell az ügyet elbírálniuk, s csak szükség esetén hallgatják meg a feleket. A határozat ellen ötnapos fellebbezési határidő biztosított, a fellebbezésről a másodfokú fórum szintén öt munkanapon belül határoz. A kérelem elbírálására a kérelmező székhelye (lakhelye) szerinti munkaügyi perben eljáró bíróság rendelkezik illetékességgel; amennyiben a sztrájk jogszerüségének, jogellenességének megállapításánál több munkaügyi perben eljáró bíróság is érintett, a kérelem elbírálására a Fővárosi Törvényszék az illetékes. ${ }^{43} \mathrm{Az}$ ágazati törvényekben szabályozott mérték (amely csak két területen van jelen: posta és személyszállítás $)^{44}$ is komoly kritika tárgyát képezi. Különös probléma e körben az, hogy e két

42 Az Sztv. 4. § (3) bekezdése alapján: „A még elégséges szolgáltatás mértékét és feltételeit törvény megállapíthatja. Törvényi szabályozás hiányában a sztrájkot megelőző egyeztetés során kell a még elégséges szolgáltatás mértékéröl és feltételeiröl megállapodni; ebben az esetben a sztrájk akkor tartható meg, ha a felek a megállapodást megkötötték, vagy ennek meghiúsulása esetén bármelyikük kérelmére a munkaügyi perben eljáró bíróság jogerős határozata megállapította a még elégséges szolgáltatás mértékét és feltételeit."

${ }^{43}$ Sztv. 4. § (4) és 5 . § (1) bekezdése.

${ }^{44}$ A 2012. évi CLIX. törvény a postai szolgáltatásokról 34. § (3) bekezdése így fogalmaz: „Sztrájk esetében a még elégséges szolgáltatás körébe az alábbi szolgáltatások biztosítása tartozik az alábbi mértékben és feltételekkel: a) a hivatalos iratok felvételének legalább heti négy napon, kézbesítésének a jogszabályban és az Egyetemes Postai Közszolgáltatási Szerződésben meghatározottaknál legfeljebb 50\%-kal hosszabb átfutási idővel történő ellátása, b) az egyetemes postai szolgáltatás keretében feladható vagy kézbesithető, az a) pontban meghatározott postai küldeménytől eltérő postai küldemények felvételének legalább minden második munkanapon, kézbesítésének a jogszabályban és az Egyetemes Postai Közszolgáltatási Szerződésben meghatározottaknál legfeljebb kétszer hosszabb átfutási idővel történő ellátása."

A 2012. évi XLI. törvény a személyszállítási szolgáltatásokról az alábbiak szerint szabályozza a sztrájkjog gyakorlását: „39. § (1) A sztrájkról szóló 1989. évi VII. törvény (a továbbiakban: Sztrájk tv.) 4. § (2) bekezdésében meghatározott, még elégséges szolgáltatás mértéke a munkabeszüntetésben érintett időszakra vetítve vonalanként a) a helyi és elővárosi személyszállitási közszolgáltatások esetén a megrendelt személyszállítási szolgáltatás mennyiségének $66 \%-a, b)$ az országos és a regionális személyszállitási közszolgáltatások esetén a megrendelt személyszállitási szolgáltatás mennyiségének 50\%-a. (2) Az (1) bekezdésben meghatározott arányokat vonalankénti bontásban, járatonként számolva, tört szám esetén felfelé kerekítve kell meghatározni. A még elégséges szolgáltatás mértéke az (1) bekezdésben meghatározott mennyiséget a munkabeszüntetés szervezői és a munkáltató közös megállapodásával meghaladhatja. (3) Az (1) bekezdésben meghatározott mértékeket a munkabeszüntetés első 24 órája tekintetében óránként, ezt követően napi bontásban kell érvényesíteni oly módon, hogy ha a munkabeszüntetés munkanapon 6:00-9:00, illetve 15:0018:00 közötti időszakot is érint, az (1) bekezdésben meghatározott mértékeknek ezen időszakokra vetítve önállóan, óránkénti bontásban is teljesülniük kell. (4) A sztrájkkal érintett közlekedési szolgáltató az (1)-(3) bekezdésben foglaltaknak megfelelö és eleget tevő menetrendtervezetet dolgoz ki és azt legkésőbb sztrájk megkezdésének időpontját két nappal megelőzően a lakosság egyidejü tájékoztatásával meghirdeti. (5) Az (1) bekezdésben meghatározott mértékü szolgáltatás nyújtása csak abban az esetben tekinthető a még elégséges szolgáltatás teljesítésének, ha az a menetrendben elöre meghirdetett útvonalon és időpontban megvalósul. (6) Az országos, regionális és elővárosi közszolgáltatások esetében a még elégséges szolgáltatás mértéke egyetlen település tekintetében sem lehet kevesebb a 27. §-ban rögzített alapellátás szintjénél. (7) Ha a munkabeszüntetésben résztvevők az (1)-(3) bekezdés szerinti szolgáltatás nyújtását akadályozzák vagy ellehetetlenítik, a közlekedési szolgáltató a munkabeszüntetés szervezőivel és résztvevőivel szemben kártéritési igénnyel élhet, továbbá jogosult a vele szemben harmadik fél által érvényesített kárigényeket rájuk továbbhárítani." 
terület esetében lehet-e egyáltalán bírósághoz fordulni az elégséges szolgáltatás megállapítása iránti kérelemmel. ${ }^{45}$

Sztrájk az előzetes egyeztetés ideje alatt, egy alkalommal, legfeljebb két órát meg nem haladó időtartamban is folytatható ${ }^{46}$ ezt nevezi a szakzsargon "figyelmeztető" sztrájknak. Véleményem szerint az Sztv. 4. § (3) bekezdése alapján az elégséges szolgáltatásban való megállapodás hiányában is lehet sztrájkot folytatni, azaz önmagában ettől (a megállapodás hiányától) nem lesz jogellenes a sztrájk a posta és a személyszállítás területén. Az más kérdés, hogy a megtartott sztrájk jogellenes lesz, ha egyébként nem felel meg a postatörvény és a személyszállítási törvény idézett és teljesen általános szabályainak. Érdekes az a szempont is, hogy miként lehet akkor figyelmeztető sztrájkot tartani, ha még az elégséges szolgáltatásról (is) folyik az egyeztetés, hiszen ennek a sztrájknak a lényege, hogy az egyeztetés alatt tartják, azaz még nincs megállapodás. Valószínúsíthető továbbá, hogy egy maximum kétórás sztrájk a törvény szerinti még elégséges szolgáltatást számos esetben nem hiúsítaná meg, amit a postaforgalomban és a közlekedésben gyakorlott szakembereknek kell megítélniük. Utóbbi esetében a járatok óránként történő „bontása” tünik a figyelmeztető sztrájk során nehezen értelmezhető szabálynak, bár technikailag nem tűnik kivitelezhetetlennek sem (gondoljunk egy jelképes, például 15-30 perces leállásra, amely jelentős és előre kiszámíthatatlan fennakadásokat okozhatna).

A figyelmeztető sztrájk kapcsán rögtön két másik problémát is felvethetünk. Egyrészt az Sztv. 2. § (3) bekezdése alapján a figyelmeztető sztrájk az egyeztetés időtartama alatt tartható, $s$ a posta- és a személyszállítási törvény alapján is van (függetlenül az elégséges szolgáltatástól) előzetes egyeztetés, azaz ennek időtartama alatt a figyelmeztető sztrájk megtartható. Másrészt: uralkodó felfogás szerint a figyelmeztető sztrájk is sztrájk, s ebből következően az elégséges szolgáltatás szabálya ebben az esetben is alkalmazandó. Utalva azonban a fent leírtakra, ebben az esetben is irányadó az, hogy az elégséges szolgáltatásra vonatkozó megállapodás hiányában is lehet sztrájkolni. Természetesen ebben az esetben is ugyanaz a kockázat marad: a bíróság utóbb esetleg megállapíthatja, hogy a sztrájkoló fél megsértette a postatörvény és a személyszállítási törvény szabályát a figyelmeztető sztrájk alatt.

Ugyanakkor a figyelmeztető sztrájkra lehetőséget adó egy hét alatt álláspontom szerint (a fent leírtakra tekintettel) nem születik bírósági döntés a rövid eljárási határidők ellenére sem. Mindez azt jelentheti, hogy lehetetlen figyelmeztető sztrájkot tartani abban a körben, ahol a még elégséges szolgáltatás nyújtása kötelező, és nincs törvényi szabály annak mértékére (a közszolgáltatások területén így a postát és a személyszállítást leszámítva mindenhol). Ezt viszont nem lehet levezetni magából a konstrukciós hibából, de a felmerülő jogi kockázat jelentős. A probléma megoldásához világos utat a bíróságok jogalkalmazása törhet (amihez persze egy konkrét jogesetre lenne szükség) vagy a jogalkotó beavatkozására és a sztrájkjog lehetőségének biztosítására, életszerübb szabályok megteremtésével a még elégséges szolgáltatások területén.

\footnotetext{
${ }^{45}$ Lásd a Fövárosi Közigazgatási és Munkaügyi Bíróság 80.Mpk.50.049/2020/4. végzését.

${ }^{46}$ Sztv. 2. § (3).
} 


\section{4. Összegzés}

A köztulajdonban álló vállalatok által ellátott - és a lakosságot alapvetően érintő közszolgáltatások területén a szakszervezeti szervezettség kimagasló (az érintett munkáltatóknál nem ritka a 60-70\%-os mértéket is meghaladó taglétszám), és a müködéshez szükséges anyagi bázis (tagdíjbevétel) is kifejezetten jelentős. Mindezek ellenére a munkavállalói érdekek hathatósabb képviselete elé jelentős gátat állítanak a jogi szabályozás hiányosságai és az az álláspontom szerint túlzott mértékü állami kontroll, amely szűkíti a menedzsmentek érdemi mozgásterét.

A 2021. évi bértárgyalások formálisan lezáródtak ugyan, de a tulajdonosi jogok gyakorlása és a közszolgáltatási feladatok ellátása során igen nagy a "keveredés”. Ennek plasztikus példáját adja az a 2021. július 27 -én megjelent kormányrendelet, ${ }^{47}$ amelynek alapján a Sztrájktörvény 3 . $§(2)$ bekezdésében meghatározott szervezeteken túl, honvédelmi és nemzetbiztonsági érdekből nincs helye sztrájknak, a honvédelmi rendszerek és létesítmények ágazati kijelölő hatósága által, a honvédelmi érdekből nemzeti létfontosságú rendszerelemmé kijelölt rendszerelemet üzemeltető légiforgalmi irányító szolgálat ellátásáért felelős szervezetnél. ${ }^{48} \mathrm{~A}$ szabályozás hátterében állhat (a hivatkozott kormányrendelet néhány nappal azt követően született), hogy az egyik - bérmegállapodásból kimaradó - légiirányítókat tömörítő szakszervezet (sajtóhírek alapján) ${ }^{49}$ munkabeszüntetést készített elő.

${ }^{47}$ 446/2021. (VII. 26.) A veszélyhelyzet során a légiközlekedés biztonságának megőrzése és a COVID-elleni védekezéshez elengedhetetlen eszközök zökkenőmentes szállítása érdekében szükséges intézkedésekről.

${ }^{48}$ Ezzel mintegy ideiglenesen (a veszélyhelyzet idejére) megtiltva a sztrájkjog gyakorlását a légiforgalom-irányító szakszemélyzet számára a 100\%-os állami tulajdonban lévő HungaroControl Zrt. vonatkozásában.

49 Jámbor Gyula: Sztrájkra készülnek a légi irányítók Ferihegyen, Magyar Nemzet https://magyarnemzet.hu/ gazdasag/2021/07/sztrajkra-keszulnek-a-legi-iranyitok-ferihegyen (2021. 07. 26.), https://magyarnemzet.hu/ gazdasag/2021/08/eles-sztrajkra-keszult-a-legiiranyitok-szakszervezete-1 (2021. 08. 24.). 